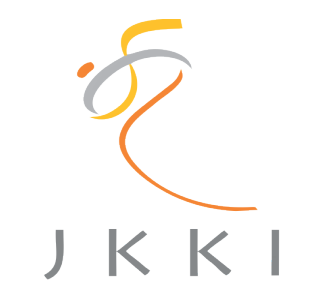

SCIEMTIR EST BASIC VITAE

\section{Jurnal Kedokteran dan Kesehatan Indonesia}

Indonesian Journal of Medicine and Health

Journal homepage: www.journal.uii.ac.id/index.php/jkki

\title{
The benefit and risk of misoprostol use: in obstetrics and gynecology
}

\author{
Sufi Desrini* \\ Departement of Pharmacology, Faculty of Medicine, Islamic University of Indonesia
}

Review Article

\begin{tabular}{ll}
\hline & ABSTRACT \\
\hline ARTICLE INFO & $\begin{array}{l}\text { Misoprostol is licensed to treat gastric ulcers but now it is widely used } \\
\text { for a variety of indications in osbtetrics and gynecology. This is called 'off- } \\
\text { Off label use } \\
\text { misoprostol }\end{array} \quad \begin{array}{l}\text { label' use. Misoprostol is cheap, stable at room temperature and easily } \\
\text { termination pregnancy }\end{array}$ \\
$\begin{array}{l}\text { to access it. Available in tablet form, it can be administred vaginally, } \\
\text { rectally, sublingually and bucally. This review explains benefit and risk of } \\
\text { misoprostol in obstetric and gynecology field. }\end{array}$
\end{tabular}

*Corresponding author:

s.desrini@gmail.com

\begin{abstract}
Misoprostol dilisensikan untuk mengobati ulkus gaster. Namun saat ini digunakan luas untuk berbagai macam indikasi dalam bidang obstetrik dan ginekologi. Penggunakan ini dikenal dengan nama "offlabel." Misoprostol adalah obat yang murah, stabil pada suhu ruangan dan mudah diperoleh. Tersedia dalam bentuk tablet, dan dapat diberikan secara intravagina, rektal, sublingual dan bukal. Tinjauan ini akan menjelaskan manfaat dan resiko misoprostol didalam bidang obstetri dan ginekologi.
\end{abstract}

\section{INTRODUCTION}

Misoprostol is a synthetic prostaglandin E1 analogue which has a capability to produce a dose-related inhibition of gastric acid and pepsin secretion, and to enhance mucosal resistance to injury so that this drug has been approved by Food and Drug Administration in the United States (US) for the prevention and treatment gastric ulcers resulting from chronic administration of non-steroidal anti-inflammatory drugs. ${ }^{1}$ However, In the practice of obstetrics and gynecology, misoprostol has been used off-label for several indication, including abortion, induction of labor, cervical ripening before surgical procedures, and the treatment of postpartum hemorrhage..$^{2-5}$ Due to misoprostol has so many benefit in the practice of obstetrics and gynecology, it is recommended by World Health Organitation (WHO) as one of method for medical abortion. In 2002, Food and Drug Federation (FDA) was removed pregnancy from the label as an absolute contraindication to misoprostol use. ${ }^{6}$

\section{CHEMICAL STRUCTURE AND PHARMACO- KINETIC OF MISOPROSTOL}

Misoprostol is a synthetic 15-deoxy-16hydroxy-16-methyl analogue of the naturally occurring prostaglandin E1. Misoprostol con- 
tains approximately equal amounts of the two diastereomers (Figure 1). Misoprostol has $382.53412 \mathrm{~g} / \mathrm{mol}$ molecular weight (MW). Misoprostol is a water-soluble, viscous liquid. Misoprostol is available in either $100 \mathrm{mcg}$ or 200 mcg tablet dosage forms. ${ }^{1}$

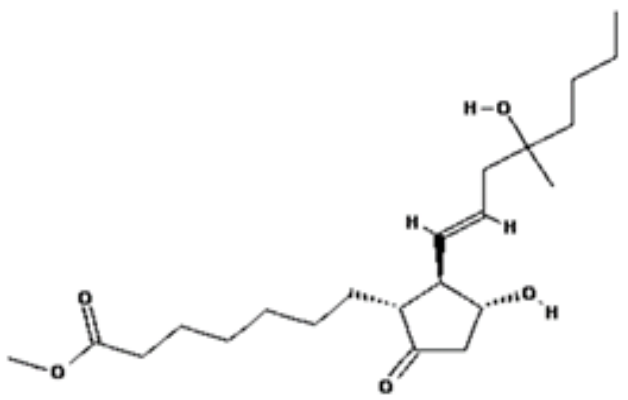

Figure 1 Misoprostol chemical structure ${ }^{1}$

There is no doses and dosing interval data of misoprostol used for any obstetrics gynecology indication that we can find in the FDA label of misoprostol because misoprostol is licenced only for treating gastric ulcer. The doses and dosing intervals were usually derived empirically from clinical trials. Misoprostol is only available in tablet form and even though misoprostol is formulated for oral use, this drug can be absorbed vaginally, sublingually, bucally and rectally. One of pharmacokinetic study reported oral misoprostol tablet can be absorbed by both rectal and vaginal routes in early pregnancy. Rectal route absorption curve is similar with vaginal route but rectal route biovailabilty is lower than vaginal route. Misoprostol is absorbed best when administrated vaginally. ${ }^{7}$

\section{BENEFIT OF MISOPROSTOL IN OBSTETRY AND GYNECOLOGY PRACTICES}

Misoprostol has been extensively studied in reproductive health. Several studies showed misoprostol is very effective for some indications such as medical abortion, induction of labor, postpartum hemorrhage.

\section{Termination of first and second-trimester pregnancy}

World Health Organization (WHO) estimates that 210 million women worldwide become pregnant/year and about two-thirds of them deliver live infants. The remaining one-third of pregnancies end in miscarriage, stillbirth, or induced abortion. ${ }^{8}$ A medical abortion is a way to end a pregnancy using medications. There are several medicine which is usually used for medical abortion including mifepristone, methotrexate, misoprostol and the combination of miferistone and misoprostol. Many studies has investigated effectiveness of misoprostol in medicine abortus, especially in a way of route administration of misoprostol interest, in which the route of administration misoprostol becomes important to affect the effectiveness of misoprostol. Vaginal administration is the most effective followed by sublingual with oral being the least effective. Sublingual misoprostol must be administered more frequent (every 3 hours) to achieve a similar effectiveness to the vaginal route, but sublingual misoprostol appears to be more acceptable for women requiring treatment for medical abortion. ${ }^{9,10}$ Faundes et al reported that the $800 \mathrm{mcg}$ of vaginal misoprostol administered every 12 hours for a maximum of three doses is recommended for termination of pregnancy up to 12 weeks. ${ }^{10}$ The recommended regimen for termination of second trimester pregnancy has been found in a retrospective study in which the regimen of $200 \mathrm{mg}$ oral misoprostol at 6-hour intervals following a $200 \mathrm{mg}$ or $400 \mathrm{mg}$ priming vaginal dose is feasible and efficacious for second trimester pregnancy termination. ${ }^{11}$

Misoprostol is not only effective when used alone, but misoprostol also effective when used with mifepristone to terminate early pregnancy. Lin et $\mathrm{al}^{12}$ reported that oral mifepristone $200 \mathrm{mg}$ followed by sublingual administration of misoprostol $600 \mu \mathrm{g} 48$ hours later resulted in a complete abortion rate of $98.5 \%$ of pregnancies $\leq 49$ days' gestation, with tolerable side effects and a high satisfaction rate of $89.9 \%$.

One of a prospective observational study has concluded that there are several predictors for successful misoprostol therapy for early pregnancy failure, such as (1) active vaginal bleeding and/or localized abdominal cholic, (2) Nulliparity or low parity not more than one, (3) Detectable vascularity by color doppler imaging (CDI) in the presumed intervillous space of missed miscarriage or anembryonic pregnancy and avascular trophoblastic tissue of incomplete miscarriage. El khali 
et al found evidence that the success rate of first-dose of vaginal misoprostol $(800 \mu \mathrm{g})$ may reach $>97 \%$ in missed miscarriage and $100 \%$ with anembryonic pregnancy in woman with early pregnancy failure presenting with a combination of active vaginal bleeding and/or abdominal colic combined with parity $0-1 .^{13}$

\section{Induction of labor}

Induction of labour is the initiation of labour using artificial means in a pregnant women with the aim to achieve vaginal delivery within 24 to 48 hours. $^{14,15}$ This is a common procedure in obstetrics. The indication for this procedure including (1) Pregnancy beyond term, (2) Prelabour premature ruptur of membrane, and (3) Fetal anomaly or fetal death. ${ }^{15}$

There are several methods to promote labor induction, including mechanical methods (eg, membrane stripping or sweeping, foley catheter insertion, and amniotomy) and pharmacologic agents (eg, oxytocin and prostaglandins). Prostaglandin such as misoprostol is an agent which has been shown to be effective to induction of labour. ${ }^{16}$ Each dosage form of misoprostol has different effectiveness. Oral misoprostol is more effective than placebo and as effective as vaginal misoprostol at achieving vaginal delivery. ${ }^{17}$ As well as the dose of misoprostol is still uncertain. A meta-analysis has been perfomed by McMaster et $\mathrm{al}^{18}$ to prove the efficacy and safety of 25 versus 50 micrograms of intravaginal misoprostol tablets for the induction of labour and cervical ripening. They found evidence that the efficacy and safety of 25 micrograms was less efficacious than 50 micrograms of vaginal misoprostol when used for labour induction and cervical ripening. But for the safety reasons, the 25-micrograms dose makes preferable.

\section{Postpartum Haemorrhage}

A blood loss of $500 \mathrm{ml}$ or more within 24 hours after birth is commonly called as post partum haemorrhage (PPH). PPH is the leading cause of maternal mortality in low-income countries and the primary cause of nearly one quarter of all maternal deaths globally. PPH is the most leading cause of death and the majority of these could be avoided through the use of prophylactic uterotonics during the third stage of labour. ${ }^{19}$

Active management of the third stage of labour which consist prophylactic administration of a uterotonic agent, controlled traction of the umbilical cord, and uterine massage is highly effective to reduce the risk of $\mathrm{PPH}$. Uterotonic agents such as oxytocin are administered shortly following delivery of the baby to stimulate uterine contractions. WHO has recommended the use of oxytocin $10 \mathrm{IU}$ as uterotonic agents during the third stage of labor for the prevention of PPH for all births. Oxytocin has been used routinely during cesarean delivery to prevent uterine atony and excessive uterine bleeding. Unfortunately, oxytocin is only available in injection form which is seldom available for births outside the health system, therefore misoprostol has attracted attention to prevent or treat postpartum haemorrhage..$^{20}$

\section{Risk of Misoprostol in Obstetry and Gyne- cology Practices}

Eventhough misoprostol has so many benefit in obstetrics and gynecology field, misoprostol has many undesirable effects. Several case study of misoprostol side effect were reported by researchers worldwide. Schoen et $\mathrm{al}^{21}$ reported A 21-year-old woman received buccal misoprostolas a ripeningagent for postdate labor induction and experienced anaphylaxis and tachysystole. Misoprostol can cause high fevers and there is an evidence that genetic susceptibility may play role in misoprostol-induced fever. Alvirefic et $\mathrm{al}^{22}$ reported the role of genetic in misoprostol induced-fever. They found that The ABCC4 single nucleotide polymorphism rs11568658 may contribute with misoprostol-induced fever.

Induction with misoprostol is one of risk factors for uterine rupture even in women with no prior cesarean delivery history. A case study which is reported by Mazzone and Woolever $^{23}$ found that a multigravida woman had a spontaneous uterine rupture after induction with misoprostol and oxytocin eventhough she did not have an unscarred uterus. Nuthalapaty et al ${ }^{24}$ found that high dose vaginal misoprostol (an initial $600 \mu \mathrm{g}$ dose of intravaginal misoprostol followed by an additional $400 \mu \mathrm{g}$ of intravaginal miso- 
prostol every 4 hours) can cause side effects including post partum hemorrhage (>500 cc), isolated fever, nausea and diarrhea higher than woman who received concentrated oxytocin plus low-dose vaginal PGE1 (277-1667 $\mathrm{mU} / \mathrm{min}$ dose of oxytocin plus vaginal misoprostol $400 \mu \mathrm{g}$ initially, followed by $200 \mu \mathrm{g}$ every 6 hours for 2 doses, then $100 \mu \mathrm{g}$ for one dose (total $900 \mu \mathrm{g}$ )). Another study reported incidence of side effects following misoprostol treatment according to gestational age at abortion. That study found that there are difference proportion of side effects between $\leq$ 12 weeks of pregnancy with up to 12 weeks of pregnancy. Less than $10 \%$ of the women with $\leq 12$ weeks reported side effects, which consisted of severe pain, chills, fever and diarhhea. In contrast with woman with $\geq 12$ weeks who have high side effect proportion. ${ }^{25}$

In cases of retained placenta, high dose misoprostol administered rectally does not give a promising result to expulsion of placenta within 30 minutes after rectal misoprostol administration and does not seem to decrease the rate of manual remove of placenta (MROP) under general anethesia. ${ }^{26}$

A case of severe hypersensitivity reaction after treatment with intravaginal administration of misoprostol has been reported. Madaan et $\mathrm{al}^{27}$ reported a 32 year primigravida presented at 12 weeks of gestation with missed abortion who received intravaginal misoprostol $800 \mu \mathrm{g}$ experiences severe hypersensitivity reaction which begins with sympotoms such as shivering, intense burning sensation and feeling of warmth over face, hands and feet after 20 minutes of intravaginal placement of misoprostol. This case must be kept in mind that hat the use of misoprostol does not rule out the possibility of the emergence of side effects.

\section{CONCLUSIONS}

Although misoprostol is not licensed for reproductive health use, it is widely used by gynecologist and obstetricians. Misoprostol has been proven to have numerous beneficial effects, including the ability to prevent and treat postpartum hemorrhage and to induce labor. However, every drugs has side effects so that needs to be used with care and based on evidence based medicine.

\section{REFERENCES}

1. National Center for Biotechnology Information. PubChem Compound Database; CID=5282381, https://pubchem.ncbi.nlm. nih.gov/compound/5282381 (accessed Nov. 13, 2015).

2. Ngai SW, Tang OS, Chan YM, Ho PC. Vaginal misoprostol alone for medical abortion up to 9 weeks of gestation: efficacy and acceptability. human reproduction 2000; 15(5):11591162

3. Zhang Y, Wang J, Yu Y, Xie C, Xiao M, Ren L. Misoprostol versus prostaglandin E2 gel for labor induction in premature rupture of membranes after 34 weeks of pregnancy. Int J Gyn Obs 2015;130:214-18

4. Dodd JM, Crowther CA. Misoprostol for induction of labour to terminate pregnancy in the second or third trimester for women with a fetal anomaly or after intrauterine fetal death. Cochrane Database of Systematic Reviews 2010, Issue4.Art.No.:CD004901. DOI:10.1002/14651858.CD004901.pub2

5. Smith J.M., Baawo S.D., Subah M., Sirtor-Gbassie V., Howe C.J., Ishola G., Tehoungue B.Z., Dwivedi V. Advance distribution of misoprostol for prevention of postpartum hemorrhage (PPH) at home births in two districs of Liberia. BMC Pregnancy and Childbirth 2014;14:189.

6. ACOG Committee Opinion, authors. Number 283, May 2003. New U.S. Food and Drug Administration labeling on Cytotec (misoprostol) use and pregnancy. Obs Gyn.2003;101:1049-50

7. Khan UR, El-Refaey H, Sharma S, Soorana, Mike. Oral,rectal, and vaginal pharmacokinetics of misoprostol. Obs Gyn 2004;103(5):866-70

8. World Health Organization (WHO), Unsafe Abortion: Global and Regional Estimates of the Incidence of Unsafe Abortion and Associated Mortality in 2003, 5th ed.2007

9. Blanchard K, Shochet T, Coyaji K, Thi Nhu Ngoc N, Winikoff B. Misoprostol alone for early abortion: an evaluation of seven potential regimens. Contraception 2005;72:91-7

10. Faundes A, Fiala C, Tang OS, Velasco A. Misoprostol for the termination of pregnancy up to 12 completed weeks of pregnancy. Int J Gyn Obs 2007;99(2):S172-7

11. Ting WH, Peng FH, Lin HH, Lu FF, Hsiao SM. Factors influencing the abortion interval of 
second trimester pregnancy termination using misoprostol. Taiwan J Obs Gyn 2005; 54(4):408-411

12. Lin M1, Li YT, Chen FM, Wu SF, Tsai CW, Chen TH, Kuo TC. Use of mifepristone and sublingual misoprostol for early medical abortion. Taiwan J Obs Gyn. 2006;45(4):321-324.

13. Elkholi D.G.E and Hefeda M.M. Potential predictors for successful misoprostol treatment for early pregnancy failure:Clinical and color doppler imaging study. Middle East Fertil Soc J 2015; 20:144-153.

14. SOGC Clinical Practice Guideline. Induction of labour. J Obs Gyn Can 2013;35(9).

15. Eke AC, Okigbo C. Mechanical methods for induction of labour: RHL commentary. The WHO Reproductive Health Library; Geneva: World Health Organization, 2012.

16. Stephenson ML, Hawkins JS, Powers BL, Wing DA. Misoprostol vaginal insert for induction of labor:a delivery system with accurate dosing and rapid discontinuation. Women's Health 2014;10(1):29-36.

17. Alfirevic Z., Aflaifel N., Weeks A. Oral misoprostol for induction of labour. Cochrane Database Sys Rev 2014:6.

18. McMaster K, Sanchez-Ramos L, Kaunitz AM. Balancing the efficacy and safety of misoprostol: a meta-analysis comparing 25 versus 50 micrograms of intravaginal misoprostol for the induction of labour. BJOG 2015;122:468476.

19. World Health Organization (WHO). WHO recommendations for induction of labour. Geneva (Switzerland): World Health Organization (WHO) 2011: 36 p.

20. World Health Organization (WHO). WHO Recommendations for the Prevention and Treatment of Postpartum Haemorrhage. World Health Organization (WHO), 2012. Available from: http://www.ncbi.nlm.nih. gov/books/NBK131942/

21. Schoen C, Campbell S, Maratas A, Kim C. Anaphylaxis to buccal misoprostol for labor induction.Obstet Gynecol 2014; 124 (2 Pt 2 Suppl 1); 466-8.

22. Alfirevic A., Durocher J., Elati A., León W., Dickens D., Rädisch S., Box H., Siccardi M., Curley P.,Xinarianos G., Ardeshana A., Owen A., Zhang J.E., Pirmohamed M., Alfirevic Z.,
Weeks A., Winikoff B. Misoprostol-induced fever and genetic polymorphisms in drug transporters SLC01B1 and ABCC4 in women of Latin American and European ancestry. Pharmacogenomics 2015; 16 (9): 919-28.

23. Mazzone ME, Woolever J. Uterine rupture in a patient with an unscarred uterus: a case study. WMJ. 2006; 105 (2); 64-6.

24. Nuthalapaty FS., Ramsey P.S., Biggio JR and Owen J. High dose vaginal misoprostol versus concentrated oxytocin +low dosevaginal misoprostol for mid-trimester labor: A randomized trial. Am J Obstet Gynecol. 2005. 193(302);1065-70.

25. Adisso S., Hounkpatin B.I.B., Komongui G.D., Sambieni O., Perrin R.X. Introduction of misoprostol for the treatment of incomplete abortion beyond 12 weeks of pregnacy in Benin. Int J Gyn Obs. 2014;s.36-s39

26. Pongsatha S, Tongsong T. Rectal misoprostol in management of retained placenta: a contradictory result. J Med Assoc Thai. 2011; 94 (5); 535-9

27. Madaan M, Puri M, Sharma R, Trivedi SS. Hypersensitivity reaction to misoprostol-a case report. Int J Clin Med. 2012;3;223-4 